\title{
Long-term series in ichthyoplankton: sole and sprat at French coast of the North Sea from 1975 to 1994
}

\section{Daniel WOEHRLING a and Geneviève LE FÈVRE-LEHOËRFF b \\ a IFREMER Centre de Nantes, B.P. 21105,44311 Nantes Cedex 3, France. \\ ${ }^{b}$ IFREMER Centre de Brest, B.P. 70, 29280 Plouzané Cedex, France.}

ABSTRACT
The sampling of eggs and larvae of sole and sprat at Gravelines (French part of the North Sea coast) since 1975 has produced a long-term series showing major interannual changes. Comparison of the results obtained on two species, one benthic and the other one pelagic, suggests some events affecting the environment that are also revealed by the holoplanktonic (appendicularia, chaetognatha) and meroplanktonic (cirripeda larvae) compartment. This study attempts also to distinguish general variations from more closely species-related fluctuations. (C) Elsevier, Paris.
RÉSUMÉ
Séries chronologiques dans l'ichtyoplancton: sole et sprat sur le littoral du sud de la mer du Nord de 1975 à 1994.

\begin{abstract}
Le traitement des séries chronologiques issues de l'échantillonnage des aufs et larves planctoniques de la sole et du sprat récoltés depuis 1975 à Gravelines (Nord) révèle des changements pluriannuels dépassant les simples fluctuations. L'étude simultanée des deux espèces, l'une benthique, l'autre pélagique, permet d'atteindre les processus généraux affectant le milieu tels qu'ils se révèlent également dans les compartiments holoplanctonique (appendiculaires, chaetognathes) et méroplanctonique (larves de cirripèdes). Des cycles pluriannuels sont mis en évidence. A partir des fluctuations caractéristiques de chaque espèce, l'étude tente de dégager les variations communes aux différents compartiments planctoniques. (C) Elsevier, Paris.
\end{abstract}

Oceanologica Acta, 1998, 21, 1, 113-121.

\section{INTRODUCTION}

The relations between hiological components and climatic changes have been established by several decades of monitoring in the North Atlantic, the English Channel and the North Sea, involving a series of CPR (Continuous Plankton Recorder) samplings. These investigations have highlighted the links between long-term climatic and biological changes, involving fish stocks, plankton and the benthos (Russell, 1935, 1936, 1939; Southward, 1962, 1963; Russell et al., 1971; Cushing and Dickson, 1976; Cushing, 1978).
Several investigations were carried out over a period of some two decades on the French coast within the framework of a research programme designed to monitor the effects of nuclear power plants on the environment and living resources. These studies were conducted mainly by IFREMER (Institut Français de Recherches pour l'Exploitation de la Mer), as well as several universities and EDF (Electricité de France), which undertakes also its own research.

At the same time, these investigations provided the opportunity to collect a long-term series relating to major ecological compartments of the benthos and pelagos, 
and to different size levels (from bacteria to fish). Several studies were conducted in order to compare pluriannual fluctuations observed at different levels, and to establish relationships between biological data and natural factors of the environment. Such mesoscale studies may yield worthwhile results in the field of general ecology, concerning long term changes in marine species, on the basis of observations made at control points, outside the thermal plume of the power plants.

The present results were obtained from a set of data gathered at Gravelines, on the French coast of the North Sea (Fig. 1), the site of the first coastal nuclear power plant constructed in France. Monitoring began at the end of 1974. An up-to-date synthesis of these studies has already been published (Le Fèvre-Lehoërff and Woehrling, 1991). Gravelines is located in the lower part of the Southern Bight of the North Sea, where shallow sandy shoals converge. The hydrodynamics is strong; alternative tidal currents run parallel to the coastline and a general residual current flows through the Dover Straits, in the direction of the North Sea. The detailed current patterns can be relatively confusing, due to winds which can even reverse the direction of tidal currents, and to the shoals which cause local unpredictable flows (S.H.O.M., 1968). The area also receives outflows from rivers (for example the small Aa river, close to the site, which yields irregular flows of water) and terrestrial outflow. This runoff is particularly high after rainy periods. In particular instances, coastal counter-currents may also divert water southwards from large European rivers, e.g. the Escaut (Schelde).

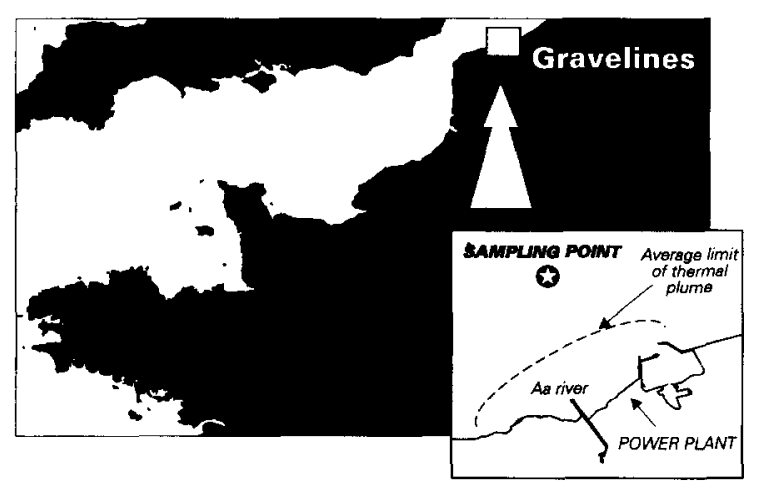

Figure 1

Location of the Gravelines area, in the Southern Bight of the North Sea.

Therefore, the site is located in a highly productive region at both primary and secondary production levels, and also for fishing activity. It lies at the end of a continuous chain of nursery grounds for flatfish scattered from one end to the other of the eastern shore of the Southern Bight. In addition, the region is close to the centre of the North Sea main spawning grounds for sole, off the Belgian coast, some 20 miles northeast of Gravelines (Wochrling, 1985). North-Sea sole spawns insḩore, following a pattern quite different from that found in the Bay of Biscay.
This area also shows a high interannual and seasonal variability in both physical and biological factors, such as temperature, salinity, phytoplankton and zooplankton abundance, fish eggs and larvae. This is due to the shallowness of the water, which offers only slight resistance to climatic fluctuations, nutrient inflow, general physical constraints and biological events.

Subsequently, our studies were focused on ichthyoplankton, especially the eggs and larvae of sole Solea solea L. and sprat Sprattus sprattus L., as well as some abundant zooplankton species, in order to investigate the relationships between major observations in the biological field and various environmental factors.

Eggs and larvae of both fish species were regularly sampled from 1975. Sole is one of the main commercial species in the local fishery and the one which provided us with results concerning both eggs and larvae (plaice spawns in the middle of the Channel, and the eggs of other flatfishes show less abundance). Sprat is not a commercial species in France, but its eggs and larvae are abundant and regularly found in the ichthyoplankton of Gravelines.

In an initial exercice, annual and seasonal fluctuations of eggs and larvae of sole and sprat were related to temperature. Comparison of the results obtained on two different fish species, one benthic and the other pelagic, may suggest some general events affecting the environment as revealed by holoplanktonic groups (appendicularia, copepoda, chaetognatha) and other meroplanktonic species (cirripeda and annelida larvae). This work is also part of the PNOC (Programme National d'Océanographie Côtière, National Coastal Oceanography Programme) research programme studying long term series. It was presented at the symposium "Long-term changes in Marine Ecosystems" held in Arcachon (France) during February 1995 (Anon., 1997).

\section{MATERIAL AND METHODS}

Temperatures measured by different research teams were pooled. Only values obtained at points located outside the thermal plume (Fig. 1) were taken into account (mean between surface and bottom, although no stratification was observed). From 1990 to 1993 , temperatures obtained at the intake channel of the plant were added to the pool. These results were completed with automatic recording immersion thermograph values transmitted by EDF. In this way, more than 2000 values were gathered over a period of 18 years.

Fish eggs and larvae were sampled several times a year; the frequency was not the same for ichthyoplankton and for the other zooplankton species, falling from up to 12 times a year to three or four times a year after 1986, with the accent on the spring period, from mid-March to the end of June. Sampling was performed by means of a Bongo gear equipped with two nets of $500 \mu \mathrm{m}$ mesh size, $3 \mathrm{~m}$ long and with a mouth of $60 \mathrm{~cm}$ in diameter, according to the standard techniques developed for the MARMAP programme (Jossi et al., 1975) devoted to ichthyoplankton; and by means of a $\mathrm{WP}_{2}$ net fitted with $200 \mu \mathrm{m}$ gauze for 
other zooplankters. As with temperature, only the results concerning points situated outside the discharge plume were taken into account.

Analysis was performed with reference either to raw data (temperatures and zooplankton abundance, the latter expressed in numbers per $10 \mathrm{~m}^{3}$ or $\log$-processed), or to integrated data: (1) 'degree-days'; (2) egg 'production' (respectively (i) temperature values and (ii) egg densities, each being cumulated over time by trapezoïdal integration); and (3) 'cumulative deviation' (see below).

(1) The degree-days calculation seems a good method to overcome short-term temperature fluctuations which can render the graph confusing. In addition, this parameter appears to be of better biological significance, assuming that the influence of temperature depends on time and not only on instantancous values. Physically, the degree-day (DD) amount is comparable to a quantity of stored energy and can be considered as a synthetic and conservative parameter, actually involved in physiological responses.

(2) The calculation of integrated egg densities is derived from the method used to calculate egg production for spawning biomass evaluation purposes (van Beek, 1989). The difference is that the raw values in our study are not corrected by stage duration (dividing each stage abundance by the stage duration in days). One reason was the low accuracy expected when applying this method to our results, since we distinguish only two development stages (respectively without and with visible embryo) instead of Riley's four (Riley, 1974): considering such long stages can lead to an underestimation of daily egg production. On the other hand, such a correction is of minor importance when dealing with comparative rather than absolute values. Besides, prior assays showed that it would not greatly affect the shape of integrated density curves. For same

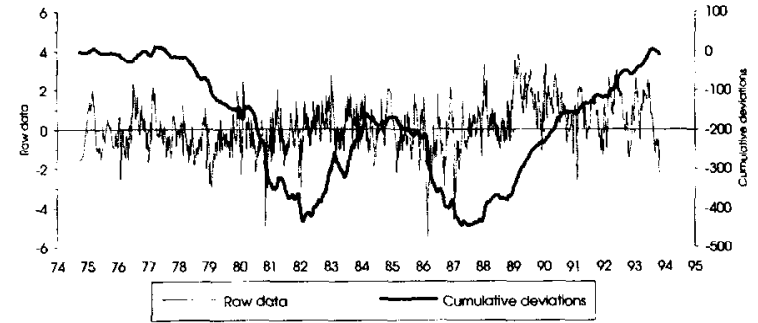

Figure 2

Temperature anomalies at Gravelines (raw data and cumulative deviation from the mean of the time-series). The raw temperature anomalies were calculated from the mean temperature over the period for each observation date (the degree-day anomalies were divided by the time interval - in days - between successive dates).

reasons, density values were not converted into numbers per surface unit.

(3) Cumulative deviation refers to a method used in the field of industrial control and transposed by Ibanez to the study of chronological data in oceanography (Ibanez et al., 1993). It consists of substracting a reference value from the data (here the mean observed for a given series), the residuals being then successively added, forming a cumulative function which in graphic form makes main changes more obvious than the raw data curves, especially when the latter show numerous fluctuations exhibiting no evident structure. This method, which is very simple and requires no special condition for application, allowing data presenting missing values to be processed, does not claim to be a model, but is merely a robust way of highlighting major events in order to suggest further lines of analysis. Incidentally, one of the aims of the present paper was to test this method as an approach.

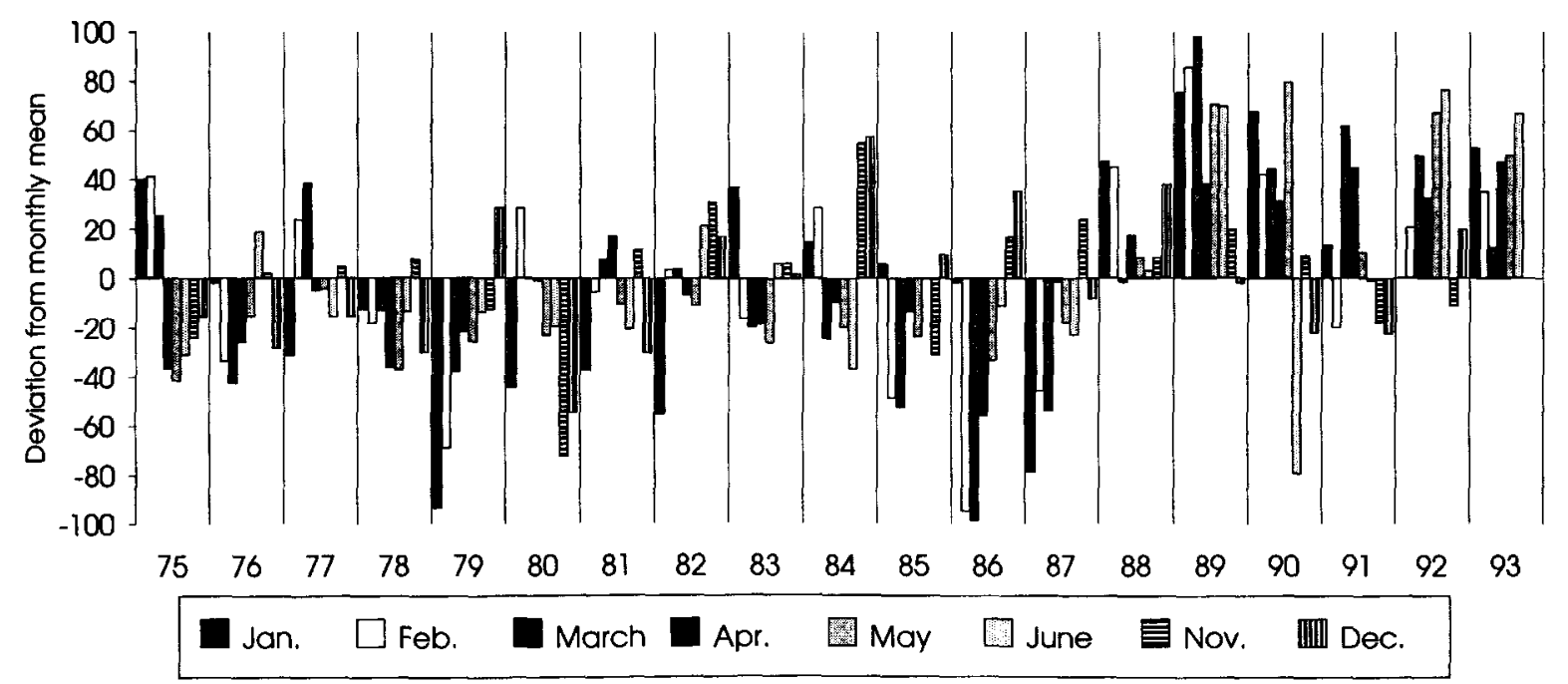

Figure 3

Monthly cumulated degree-days, expressed as absolute deviations from the mean for each month (from November to July). 


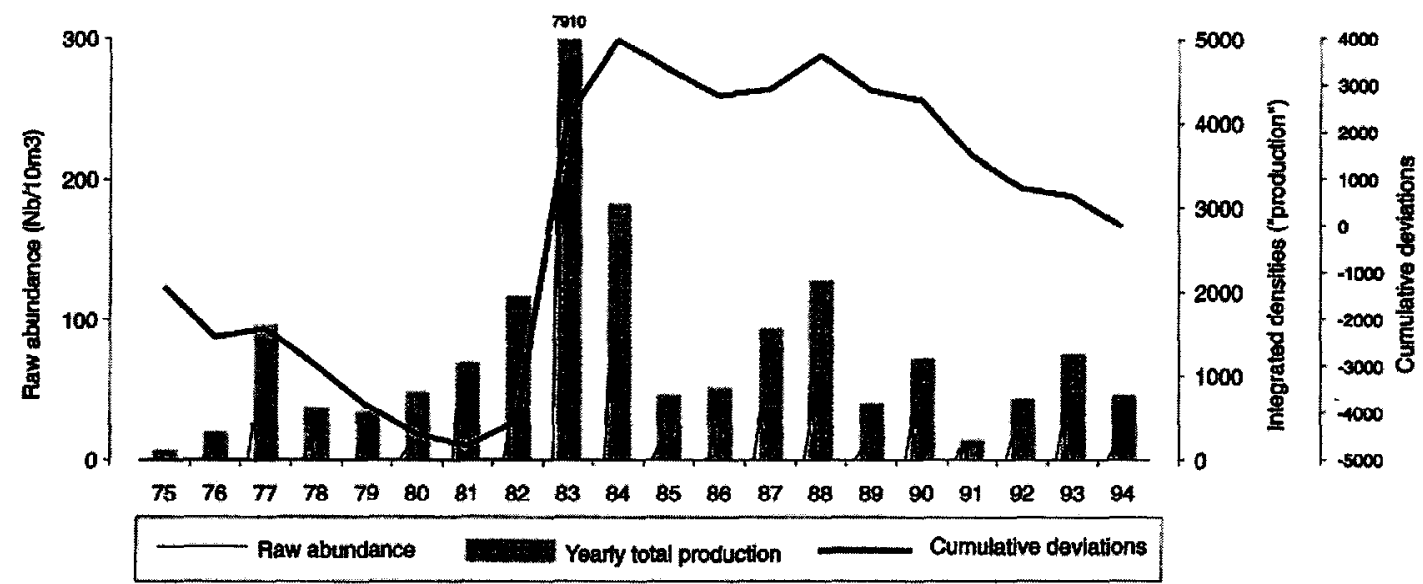

Figure 4

Pluriannual variations of sole spawning at Gravelines, expressed as raw egg abundance, annual total production (yearly integrated densities) and cumulative deviation of this production considering the mean of the annual values.

\section{RESULTS}

\section{Temperature}

Gravelines shows a large seasonal deviation in water temperature, with a northward gradient starting from the Western Channel, and continuing up to the shallower waters of the North Sea. This phenomenon is emphasized in coastal areas. It comes as no surprise that the fluctuations of water temperature are well correlated to air temperature, the latter also following atmospheric pressure patterns (Fromentin and Ibanez, 1994).

Raw data of the time- series show a slight pluriannual oscillation in the curve wrap, with pronounced periodic variation notably in connection with the cold winters of 1978-79, 1985-86 and 1986-87. These temperature depressions also correspond to periods of instability, as revealed by wind data analysis (Le Fèvre-Lehoërff $e t$ al., 1995).

Seasonal correction for temperature was taken into account when considering the deviation from the mean, dividing the DD residuals for each date by the time interval (in days) between two successive observations. These values remain confusing when looking at raw data; but when cumulated, they show a more obvious feature, confirming the previous periodicity, with two depressions around 1982 and 1987 (Fig. 2) and a slight increase around 1984-85. Different methods where tested, considering either raw temperature, raw DD instantaneous deviations, or yearly-cumulated DD from 1 January onwards. All cumulative deviation curves showed roughly the same feature. Net monthly amounts of DD were also expressed as deviations from monthly means (Fig. 3).

\section{Sole}

In northern areas, spawning of sole begins usually in March and May last until June, sometimes as late as July. At Gravelines, spawning was regularly observed during this period, with a peak between mid-April and mid-May. Cold winters induce late spawning and shifts of the main period, the latter appearing never to exceed one month.

Egg abundance (Fig. 4) shows a good reproducibility according to the irregular sampling, the maximum range being usually between 3 and 8 per $\mathrm{m}^{3}$ (excepting the high values observed in 1983). Annual production follows raw abundance, showing a maximum in 1983, surrounded by two depressions around 1979 and 1986-87. The high production observed between 1982 and 1984 explains the steepening of the slope of the cumulative deviation curve, showing changes similar to those observed for temperature (Fig. 2).

The depressions follow the cold winters of 1979, 1986 and 1987. They are particularly visible when plotting the early egg production (the values reached by 1 April obtained by interpolation of the observed densities, followed by trapezoidal integration until this date). Comparing these values with DD amounts relative to the first months of each year makes the induction of late spawning by low winter temperatures obvious (Fig. $5 a$ ). The depression of 1979 is particularly pronounced, probably because a cold December added its effects to further low temperatures; this was also the coldest year, considering the whole period from November (1978) to June (1979), (Fig. 3). A slight depression is also noticed in 1982, due to cold December and January. Inversely, the peak of 1983 follows mild winter temperatures starting as soon as November 1982.

Production reached at a given date (e.g. the beginning of April - Fig. 5a - or May), and obtained by interpolation. can be considered as an index of precocity of spawning although biased by total annual abundance (a high production value calculated for a given date from the curve can also be due to a high value of the maximum, and not only to the shift of the main period). Therefore, in order to investigate selectively the spawning kinetic, we considered the relative early production at the same time (percentage of early production compared to total 

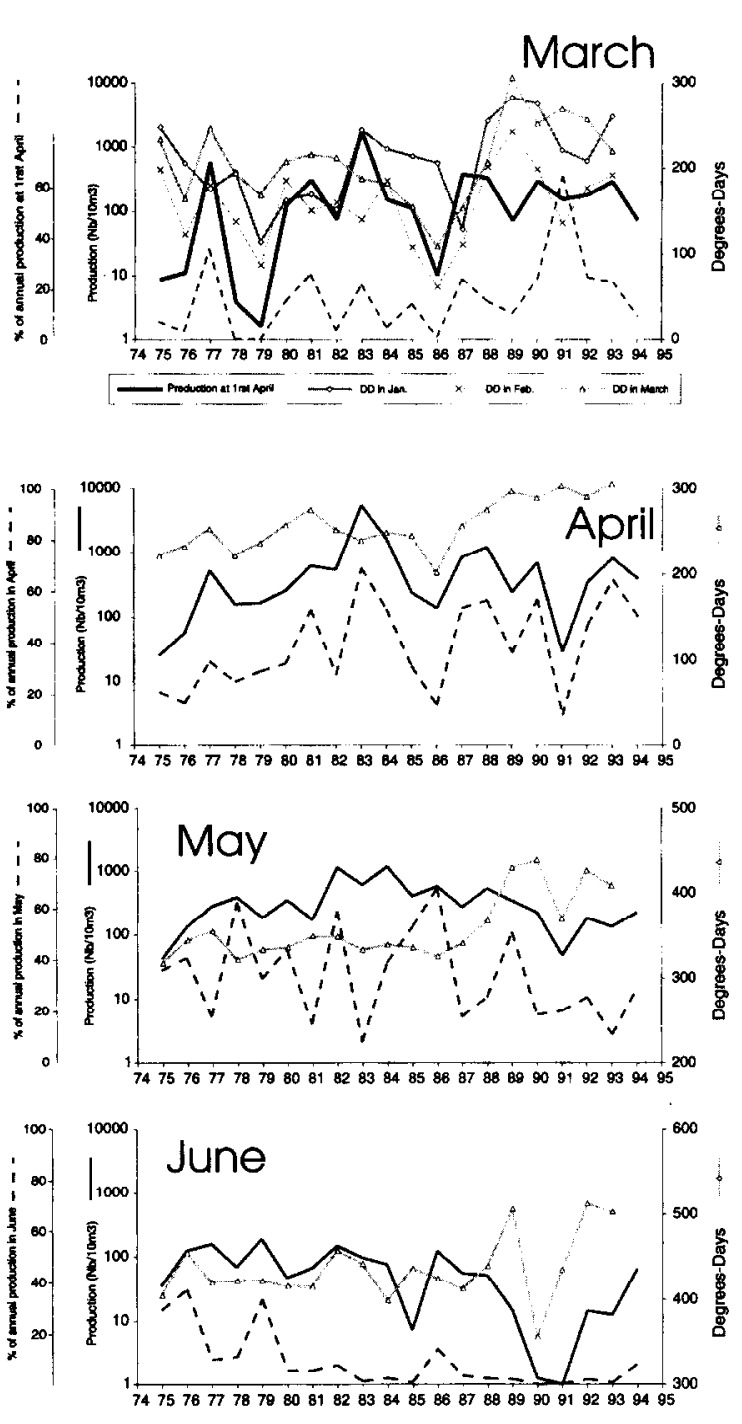

Figure 5

Monthly sole egg production (integrated densities) until the beginning of month $n$ minus similar values for the month $\mathrm{n}-1$ (current month); a: March (= roughly production at I April), b: April, c: May, d: June (absolute and relative values) compared to monthly degree-day amounts.

production of that year - Fig. 5). Confrontation of all these results confirms late spawning during the years 1978, 1979, 1982 and 1986, and early spawning in 1977 and 1983. In addition, we can observe (Fig. 6) that yearly differences of raw production at the beginning of each month, though they persist, decrease from April to June, further spawnings being unable to compensate completely for early deficits in case of spawning delay.

Net monthly egg production (Fig. 5) shows a better relation to the DD monthly amount in early spring, where the depressions of the 1979 and 1986 temperatures induce a strong response at the egg production level. This may be of particular importance, since March and April can account for 20 to 80 percent (as in 1983) of the total spawning (Fig. 5). Most eggs are generally spawned during the two

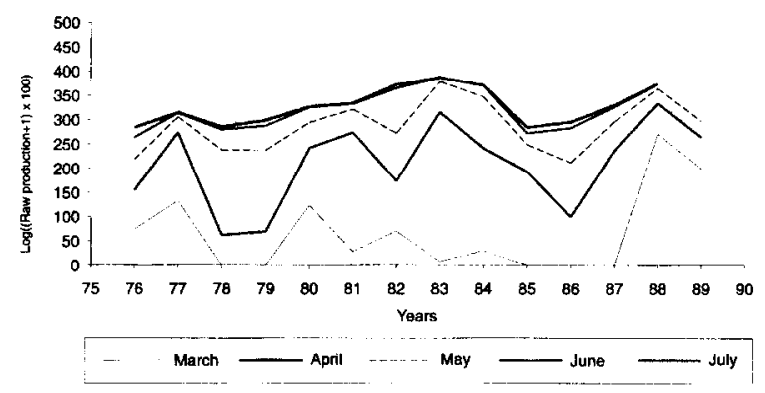

Figure 6

Seasonal evolution of sole spawning as shown by egg production at the beginning of each month. Production at 1 July can be considered as total yearly production (a good approximation is given by production at I June). Important deficits of early production are compensated by late spawns of relative importance.

months April and May, usually accounting for $40-50 \%$ of the total spawn.

Further spawning shows a less evident relationship with temperature. This is the case for the slight drop of egg production in May and June 1991, corresponding to the decreasing DD amount although beginning earlier (Fig. $5 b$ to $d$ ), and the slight peaks in relative production in June for the years 1979 and 1986 (Fig. 5d), which show no relation with DD peaks. But such late spawning cannot yet be held to be negligible, since it ensures about 20 $30 \%$ of total production. Late unexplained spawning peaks appear as a slight compensatory mechanism as spawning is delayed by cold conditions in winter or spring. In 1986, spawning began in May and, despite its importance, was not supported by any particular temperature increase.

In accordance with these results, the consequences of early peaks remain visible in June, and cannot be entirely explained by the integration of early high values, since the quantities of further spawning can be important, for instance in 1983 where the amount produced at the beginning of April is less than $20 \%$ of the annual production. By way of comparison, in 1977 , up to $40 \%$ of the annual spawning was reached at this date, but further spawning was less important than in 1983, resulting in a lower peak. On the other hand, in 1991, where this early production reached about $50 \%$ of the total, annual production shows a depression due to deficient late spawning. As generally observed, a high further production when spawning is early and, on the contrary, a low compensation when spawning is late, may of course increase the precocity index based on apparent raw production at the beginning of the spawning season. Therefore, it appears that yearly egg production is mainly determined by winter and early spring temperatures, late spawning being hardly able to compensate for initial production deficits irrespective of the spring temperatures. Conversely, initial high productions are often emphasized by further spawnings. One probable explanation of this phenomenon is a more intensive onshore migration by genitors after mild winters, which first induce early spawning, and secondly - and independently - ensure high spawning during spring, whatever the following 
temperatures (assuming that the latter are not excessively low).

Therefore, the effect of temperature seems to be rather complex and can be interpreted as a convergence of two effects: 1) a local and physiological effect on spawners; 2) a probable effect on migration patterns. Mild winters may induce early spawning and a greater amount of eggs, acting both on individual production and on the number of adults migrating onshore. It is known that the reversal of thermal gradients at the onset of spring determines the onshore migrations of adults. Sole populations exhibit a seasonal and short migration pattern, staying offshore during winter (as shown by several authors, namely Riley, 1974, Deniel, 1981, and more recentely Dorel et al. 1991, and Koutsikopoulos et al. 1995 for the Bay of Biscay); at the onset of spring, they return to the coastal feeding and nursery areas, which are also spawning grounds for the populations of the Channel and North Sea. Such a mechanism may first emphasize the differences observed in early egg production after warm or cold winters. Secondly, it may explain why spring spawning remains important after mild winters, whatever the further temperature fluctuations (for instance, in 1983, spring temperatures were lower than the mean), and the relative difficulty in reaching the same annual production after cold winters, due to initial low production associated with further relative low spawning, fewer adults being present inshore.

Nevertheless, a certain compensation being observed, it may be suggested that the increasing spring temperature either stimulates spawning on a constant number of adults, or acts by inducing more further onshore migration. Whatever the mechanism, spring temperatures may modulate the apparent spawning rate, rather than the total quantities spawned. Thus, they may cause slight additionnal shifts of the spawning peak, the main period remaining induced by previous temperatures. Of course, it must be remembered that spring temperatures also act on food availability. Temperature may also determine the end of

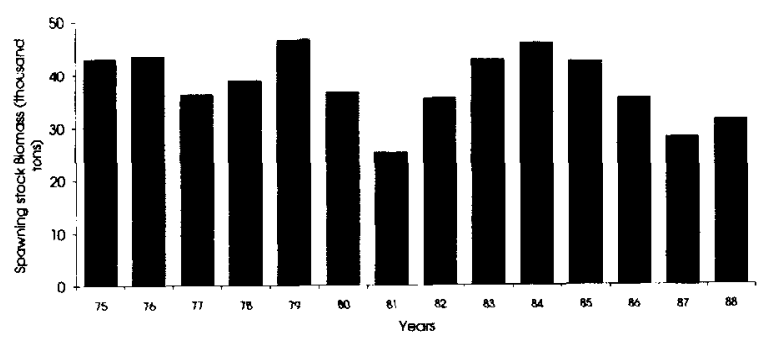

Figure 7

Spawning stock biomass of sole in the North Sea from 1975 to 1988 (Reference: Anon., 1989).

the breeding period. In a previous paper (Woehrling and Le Fèvre-Lehoërff, 1993), the hypothesis was advanced that temperature could act at two main periods, winter temperatures being responsible for total production and spring temperatures for the spawning kinetic.

It seems that variable migration patterns modulate the local spawning figure, since the fluctuations of cgg abundance at Gravelines do not exactly follow the annual variations of spawning stock biomass (SSB) of North Sea Sole (Anon., 1989). Nevertheless, some similarities appear, especially the high abundances around the year 1983 (Fig. 7). More interesting are the relatively important SSB values observed during the years 1979 and 1986, making plausible our hypothesis of smaller number of spawners migrating onshore during cold winters and early spring, thus leading to late spawning and low production at Gravelines despite normal spawning biomass at the North Sea level. Nevertheless, relatively good values of SSB at a large scale could explain good restauration of late spawning during these years.

\section{Sprat}

The two most abundant ichthyoplankton species present at Gravelines, sole and sprat, have been compared. Despite the rather different ecology of the adults - the first is
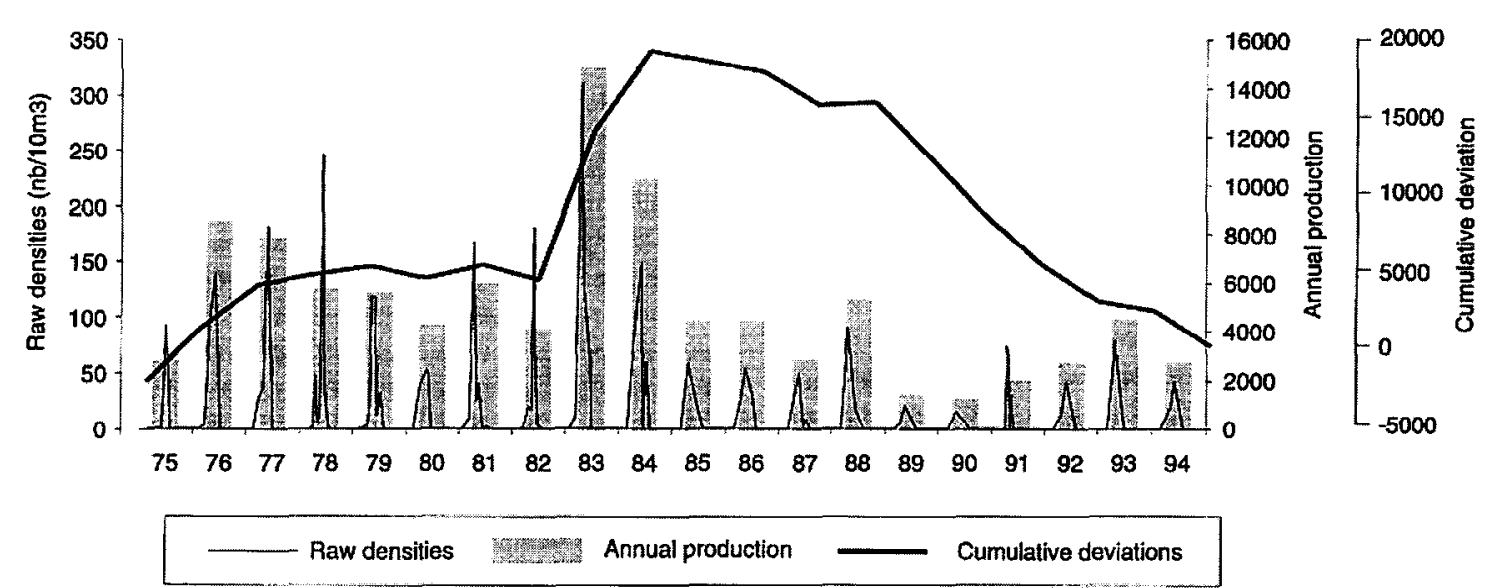

Figure 8

Pluriannual variations of sprat spawning at Gravelines, expressed as raw egg abundance, annual total production (yearly integrated densities) and cumulative deviation of this production considering the mean of the annual values. 
benthic, the second pelagic - these two species have some similar characteristics, for example an inshore habitat and a relative sedentary behaviour. Although sprat is known as a pelagic and migrating species, North Sea populations are classically described as sedentary (Ehrenbaum, 1905; Da Silva, 1973; Schultz et al., 1974; Johnson, 1978); in fact, we noticed a regular spawning cycle at Gravelines. That was not the case for other pelagic migrators like mackerel or horse mackerel. Therefore, in comparing sole and sprat, we hoped to highlight some general processes affecting the environment.

Like sole, sprat is a spring spawner whose main spawning period occurs rather later than that of Sole. Annual fluctuations in abundance show some similarity with sole, especially from the 1980s onward (Fig. 8). The similarity of the features indicates some general process or, at least, some common spawning mechanisms, and probably the double effect of temperature on reproductive physiology and spatial distribution as well.

\section{Other species}

Results concerning some other parameters and zooplanktonic organisms were analysed. A typical U-shaped curve is noticed for chlorophyll $a$ (Fig. 9) and for the appendicularian Oikopleura dioica (Fig. 10), both being strongly correlated with temperature and showing a slope change centred on 1983 (as observed for ichthyoplankton). The curve of Oikopleura dioica shows very sharp positive slopes at the end of 1979 , at the beginning of 1983 and in spring 1986. It may be recalled that the years 1983 and 1986 have already been mentioned for the importance of the spring spawning of sole, whose larvae feed largely on appendicularians, like most flatfish larvae (Wyatt, 1974).

A surprising result is the similarity of the cumulative deviation comparing the chaetognath Sagitta setosa (Fig. 11) and temperature (Fig. 2). The curves show closely the same feature, with a peak centred on 198485 surrounded by two depressions around 1982 and 1987 . The yearly evolution of Sagitta shows also a 7-year cycle and its features show the same periods of changes as Cirriped nauplii, with opposing phases (Le Fèvre-Lehoërff et al., 1995).

\section{DISCUSSION}

The present results reveal some interesting and coherent features, despite sampling variability and irregular frequency, especially from the year 1989 onward, which could explain some discrepancies in the data. Nevertheless, abundance cycles of fish eggs seem to be well reproduced. Possible spatial variability of the sampling data on a given site is overcome assuming a lagrangian point of view, the restricted studied area being considered as a spatial window representative of the mean values in a larger region. This is confirmed by the hydrodynamic pattern in the vicinity of Gravelines (see above), the movements of the water bodies reducing patchiness and vertical stratification, according to shallowness of the waters off these sandy shores.

Another difficulty could emerge from the general spawning pattern due to sampling frequency. Yet, although sole is

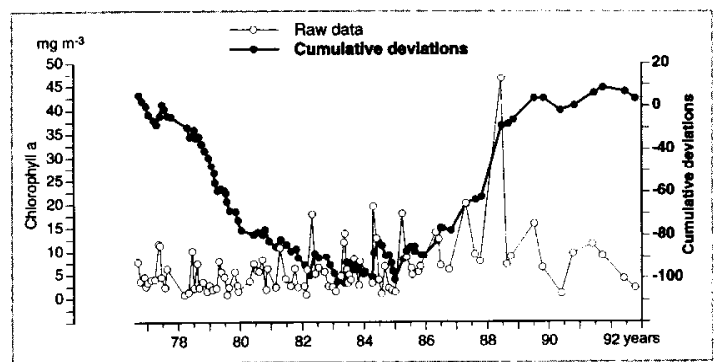

Figure 9

Pluriannual variations of Chlorophyll a at Gravelines.

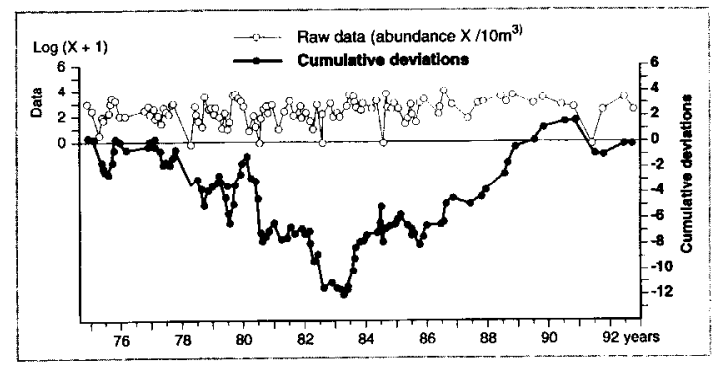

Figure 10

Pluriannual variations of Oikopleura dioica at Gravelines.

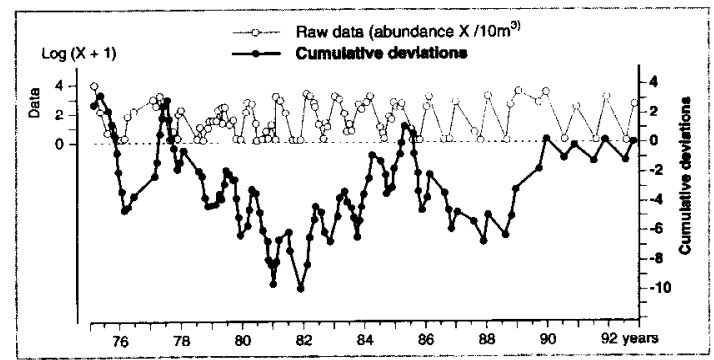

Figure 11

Pluriannual variations of Sagitta sctosa at Cravelines.

described as a serial spawner, the blending of individuals which differ in age and size and whose spawnings are not simultaneous, will make the global spawning pattern rather continuous.

Physiologically, temperature may act principally: 1) on spawning abundance during the maturation period by modifying the quantity of potentially spawned eggs, directly or through food availability and, later, by determining the atresis rate (Lahaye, 1972; Deniel, 1981); and 2) on the spawning kinetic (Woehrling and Le FèvreLehoërff, 1993). The first parameter depends mainly on winter temperatures (if we neglect the atresis rate, which is enhanced by warm temperatures at the beginning of summer); while the second is governed both by winter temperatures determining the onset of spawning, which starts when they reach about $7^{\circ} \mathrm{C}$ (Flüchter, 1965; Riley, 1974; Fonds, 1979), and spring temperature, an increase in which may modify the spawning rate. The effect of temperature can even be more complex: egg diameter, 
for instance, may influence survival as well as spawning intensity (Rijnsdorp and Vingerhoed, 1994). In addition, spawning delay after cold winters may have an indirect influence on the spawning kinetic by 'concentrating' the spawn over a shorter period. In addition, temperature changes influence the spatial distribution of spawners.

Our observations probably reflect both the reproductive pattern of local population and variations in spawning distribution in the vicinity, which may affect egg distribution. Cold winters probably retain the spawners offshore at the beginning of the spawning season, leading to reduced ovarian egg stock as they reach the coastal areas. In addition, the main spawning ground of the North Sea may shift as a consequence of inshore and offshore migrations induced by coastal temperatures. These migrations are known to be important in the Southern Bight, where shallowness causes low resistance of water bodies to air temperature. It would not be surprising if those shifts in the distribution of spawners affect the local egg densities, emphasizing the effects of shifts in the timing of the spawning period. In addition, shifts of egg distribution may affect yearly egg abundance in the Gravelines area after a diffusion process. Such a hypothesis can explain main variability, and suggests that local relationship between temperature and spawning must be analysed on a regional scale.

Nevertheless, beyond a rather rough comparison, some results suggest a general periodic pluriannual variation. Previous studies suggested a 7-8 year cycle (Woehrling and Le Fèvre-Lehoërff, 1993) after processing of the Gravelines data up to 1989, which recalls Russell's cycle in the Channnel. Such a periodic variation was also mentioned for some species by Le Fevre-Lehoërff et al. (1995). It may be noted that a period of 7-8 years was also detected in the framework of other studies, for example the analysis by Bordat (1994) of sea surface temperatures of the Bay of Biscay (with oscillations of the maxima showing also low values around 1979 and 1986-87), and the work of Fromentin and Ibanez (1994) exhausting a 90-96 month cycle in air temperature for several French sites (including Dunkerque, close to Gravelines), showing the same years for low values. Two explanations for this 7-8 year cycle are offered by Fromentin and Ibanez, without proposing that one or the other should be retained: 1) it represents a harmonic of a larger period, revealed from the results of the Genoa spectrum; 2) it is in relation with the pole tide, which has a period of seven years.

\section{CONCLUSION}

Time-series analysis of water temperature and main ichthyoplanktonic species sampled in the coastal area of Gravelines over a 20 -year period reveals some biological phenomena which demonstrate specific characteristics but also tally with general features observed in other compartments and levels, such as hydroclimatic parameters and other zooplankters.

The spawning of sole in inshore areas shows good agreement with pluriannual temperature variations, especially during the winter-spring period, inducing firstly the local production level and secondly the spring spawning kinetic.

One of the principal observations to emerge from this set of results is the general trend in major environmental changes at the horizon of the 1980s and the 7-year cycle which can be recognized in different biological descriptors.

Numerical processing of cumulative sums provides a useful description of main changes which cannot be easily determined from raw variation curves. It permits confirmation of cycles which are detected both in meteorological parameters and in species whose life span and trophic levels can be very different, such as Chaetognaths and Appendicularians, as well as in sole and sprat eggs, owing to a relatively broad spectrum. This suggests that long-term general changes lie behind short-term fluctuations governed by specific biological characteristics, and introduce strong modulations at a larger scale of time, and probably space.

Temperature must be regarded both as a biological factor, and as an indicator of more general changes. Fishes themselves seem not able to escape general features revealed at the planktonic level. This can be encouraging for planktonic studies as a good indicator of temporal features and climatic changes.

\section{Acknowledgements}

This study forms part of the multidisciplinary research programme IGA (Impact des Grands Aménagements) conducted by IFREMER (Institut Français de Recherches pour l'Exploitation de la Mer) and mainly supported by EDF (Électricité de France).

This work is also part of the PNOC (Programme National d'Océanographie Côtière, National Coastal Oceanography Programme) research programme on time-series topic.

The authors wish to acknowledge the assistance received from all involved in at-sea data collection and sampling surveys, in laboratory studies and in data analysis since 1975.

\section{REFERENCES}

Anon. (1989). Report of the North Sea flatfish working group. Cons. int. Explor. Mer. CM 1989/Assess: 6.

Anon. (1997). Long-term changes in Marine Ecosystems, Oceanologica Acta, 20, 1, 332 p.

van Beek F.A. (1989). Egg production of North Sea sole in 1988. ICES C.M. 1989/G:45.
Bordat D. (1994). Analyse des séries chronologiques des paramètres hydroclimatiques du golfe de Gascogne. Rapport IFREMER.

Cushing D.H., R.R. Dickson (1976). The biological response in the sea to climatic changes, Adv. mar. Biol. 14, 1-122.

Cushing D.H. (1978). Biological effects of climatic changes, Rapp. P.V. Réun. Cons. int. Explor. Mer 173, 107-116. 
Da Silva S.S. (1973). Aspects of the reproductive biology of the sprat Sprattus sprattus (L.) in inshore waters of the west coast of Scotland J. Fish. Biol. 5, 6, 689-705.

Deniel C. (1981). Les poissons plats en baie de Douarnenez: reproduction, croissance et migration des Bothidae, Scophthalmidae, Pleuronectidae, Soléidae. Thèse d'État, Université de Bretagne Occidentale, Brest, $476 \mathrm{p}$.

Dorel D., C. Koutsikopoulos, Y. Desaunay, J. Marchand (1991). Seasonal distribution of young sole Solea solea (L.) in the nursery ground of the Bay of Vilaine (northern Bay of Biscay), Neth. J. Sea Res. 27, 297-306.

Ehrenbaum E. (1905). Eier und Larven von Fischen. Nordisches Plankton 7nol.

Flüchter J. (1965). Versuche zur Brutaufzucht der Seezunge Solea solea in kleinen Aquarien, Helgolander Wiss. Meeresuntersuch. 12, 396-403,

Fonds M. (1979). Laboratory observations on the influence of temperature and salinity on development of the eggs and growth of the larvae of Solea solea (Pisces), Mar. Ecol. Prog. Ser. 1, 91-99.

Fromentin J.M., F. Ibanez (1994). Year-to-year changes in meteorological features of the French coast during the last half area century. Examples of two biological responses, Oceanologica Acta 17, 3, 285-296.

Ibanez F., J.M. Fromentin, J. Castel (1993). Application de la méthode des sommes cumulées à l'analyse des séries chronologiques en océanographie, C.R. Acad. Sci. 316, 745-748.

Johnson P.O. (1978). Report on the sprat sampling from ICES young fish surveys undertaken in February 1976, 1977 and February-March 1978, Cons. int Explor. Mer, Comité des poissons pélagiques, H: 31.

Jossi J.W., R.R. Marak, H. Petersen (1975). At-sea data collection and laboratory procedures. Marmap survey I manual, Marmap program Office, National Marine Fishery Service Ed., Washington D.C.

Koutsikopoulos C., D. Dorel, Y. Desaunay (1995). Movement of sole (Solea solea) in the Bay of Biscay: coastal environment and spawning migration, J. Mar. Biol. Ass. U.K. 75, 109-126.

Lahaye J. (1972). Cycles sexuels de quelques poissons plats des côtes bretonnes, Rev. Trav. Inst. Pêches Marit. 36, 2, 191-207.

Le Fèvre-Lehoërff G., F. Ibanez, P. Poniz, J.M. Fromentin (1995). Hydroclimatic relationships with planktonic time series from 1975 to 1992, in the North Sea off Gravelines, France, Mar. Ecol. Prog. Series 129, 269-281.

Le Fèvre-Lehoërff G., D. Woehrling (1991). Aménagement industriel du littoral et surveillance de l'environnement: la centrale nucléaire de Gravelines (1975 à 1989) Oceanologica Acta vol. sp. 11, 299-311.

Riley J.D. (1974). The distribution and mortality of sole eggs (Solea solea L.) in inshore areas. In: The early life history of fish. Ed. by J.H.S. Blaxter. Springer Verlag, Berlin, p. 39-52.

Rijnsdorp A.D., B. Vingerhoed (1994). The ecological significance of geographical or seasonal differences in egg size in Solea solea (L.), Neth. J. Sea Res. 32, 255-270.

Russell F.S. (1935). On the value of certain plankton animals as indicators of water movements in the English Channel and North Sea, J. Mar. Biol. Ass. U.K. 20, 309-332.

Russell F.S. (1936). The importance of certain plankton animals as indicators of water movements in the western end of the English Channel, Rapp. Cons. int. Explor. Mer 100, 7-10.

Kussell F.S. (1939). Hydrographical and biological conditions in the North Sea as indicated by plankton organisms, J. Cons. int. Explor. Mer 14, 171- 192.

Russell F.S., A.J. Southward, G.T. Boalch, E.I. Butler (1971). Changes in biological conditions in the English Channel off Plymouth during the last half century, Nature 234, 468-470.

Schultz H., P. Ernst, O. Rechlin (1974). Occurence and stock composition of North Sea sprat in 1973, Cons. int. Explor. Mer, Comité des poissons pelagiques (nord), H: 25.

S.H.O.M. (Service Hydrographique et Océanographique de la Marine) 1968. Courants de marée dans la Manche et sur les côtes françaises de l'Atlantique. S.H.O.M. Ed., Paris.

Southward A.J. (1962). The distribution of some plankton animals in the English Channel and approaches. II: Surveys with the Gulf III high-speed sampler, J. Mar, Biol. Ass. U.K. 42: 275-374.

Southward A.J. (1963). The distribution of some plankton animals in the English Channel and approaches. III . Theories about longterm biological changes including fish, J. Mar. Biol. Ass. U.K. 43: 1-29.

Woehrling D. (1985). Données sur la population de soles du secteur de Gravelines (Nord). Contribution à la connaissance des oeufs, larves et juvéniles. Rapport IFREMER pour EDF, 2 vol., 237 p.

Woehrling D., G. Le Fèvre-Lehoërff (1993). Fluctuations pluriannuelles de la ponte de la sole Solea solea (L.) sur le littoral du sud de la mer du Nord. J. Rech. Oceanogr. 18, 74-79.

Wyatt T. (1974). The feeding of plaice and sand-eel larvae in the Southern Bight in relation to the distribution of their food organisms. In: The early life history of fish. Ed. by J.H.S. Blaxter. Springer Verlag, Berlin. 